\title{
Substrate Temperature Effect on Charge Transport Performance of ZnO Electron Transport Layer Prepared by a Facile Ultrasonic Spray Pyrolysis in Polymer Solar Cells
}

\author{
Jiang Cheng, Rong Hu, Qi Wang, Chengxi Zhang, Zhou Xie, Zhangwen Long, \\ Xin Yang, and Lu Li \\ New Materials Technology Institute, Co-Innovation Center for Micro/Nano Optoelectronic Materials and Devices, \\ Chongqing University of Arts and Sciences, Chongqing 402160, China
}

Correspondence should be addressed to Xin Yang; 371993708@qq.com and Lu Li; lilu25977220@163.com

Received 3 August 2015; Accepted 25 October 2015

Academic Editor: Ahmad Umar

Copyright (C) 2015 Jiang Cheng et al. This is an open access article distributed under the Creative Commons Attribution License, which permits unrestricted use, distribution, and reproduction in any medium, provided the original work is properly cited.

\begin{abstract}
A novel ultrasonic spray pyrolysis for high-quality $\mathrm{ZnO}$ films based on zinc-ammonia solution was achieved in air. To investigate the structural and optical properties as well as the performance of polymer solar cells (PSCs), ZnO films at different substrate temperatures and thicknesses were prepared. The performance of poly(3-hexylthiophene):[6,6]-phenyl $\mathrm{C}_{61}$-butyric acid methyl ester (P3HT:PCBM) based PSC was found to be improved due to the $\mathrm{ZnO}$ films. The crystal structure and roughness of the $\mathrm{ZnO}$ films fabricated at different temperatures were found to affect the performance of PSCs. The optimized power conversion efficiency was found to be maximum for PSCs with $\mathrm{ZnO}$ films prepared at $200^{\circ} \mathrm{C}$. The growth process of these $\mathrm{ZnO}$ films is very simple, cost-effective, and compatible for larger-scale PSC preparation. The precursor used for spray pyrolysis is environmentally friendly and helps to achieve $\mathrm{ZnO}$ film preparation at a relative low temperature.
\end{abstract}

\section{Introduction}

Bulk heterojunction (BHJ) PSCs have received a great deal of attention due to their light weight, flexibility, and lowcost fabrication by using solution processing methods [13]. Typical BHJ PSCs are fabricated with a transparent conductive anode, an electron-transporting layer (ETL), a holetransporting layer (HTL), and an active layer sandwiched between the ETL and HTL $[4,5]$. N-type metal oxides such as titanium oxide $\left(\mathrm{TiO}_{2}\right)$, zinc oxide $(\mathrm{ZnO})$, and cesium carbonate $\left(\mathrm{Cs}_{2} \mathrm{CO}_{3}\right)$ have previously been reported as an efficient ETL in PSCs [6, 7]. Among the n-type metal oxides used in PSCs, $\mathrm{ZnO}$ is a promising candidate due to its good transparency across the entire visible spectral range, high electron mobility, environmental stability, and low cost. Furthermore, the band edge cut-off of $\mathrm{ZnO}$ is nearly $370 \mathrm{~nm}$ and this protects the photoactive layer from UV damage whilst also improving the life of PSCs [8]. Recently, triple-junction PSCs using $\mathrm{ZnO}$ as ETL with high power conversion efficiency (PCE) of over 11.5\% have been fabricated by Yang's group [9].
Solution processing techniques such as spin-coating and spray pyrolysis are particularly appealing as they offer a cheap and efficient way of preparing $\mathrm{ZnO}$ thin films. Spincoated $\mathrm{ZnO}$ films using a precursor composed of zinc acetate $\left(\mathrm{Zn}\left(\mathrm{CH}_{3} \mathrm{COO}\right)_{2}\right)$, ethanolamine $\left(\mathrm{NH}_{2} \mathrm{CH}_{2} \mathrm{CH}_{2} \mathrm{OH}\right)$, and 2methoxyethanol $\left(\mathrm{CH}_{3} \mathrm{OCH}_{2} \mathrm{CH}_{2} \mathrm{OH}\right)$ have been reported as a means to fabricate efficient inverted PSC devices $[1,10-$ 12]. In these studies, the $\mathrm{ZnO}$ films required long annealing times of 30 minutes to 1 hour. Even so, the conventional spin-coating approach is only suitable for lab-scale $\mathrm{ZnO}$ preparation, limiting potential roll-to-roll variations. To acquire large-scale $\mathrm{ZnO}$ films, other techniques such as blade coating, inkjet printing, and spray pyrolysis are required [1315]. With the advantages of continuous production, high efficiency, and excellent control of chemical uniformity, spray pyrolysis is able to fabricate $\mathrm{ZnO}$ based devices in a rollto-roll processing way. However, traditional spray pyrolysis using zinc acetate or zinc nitrate solution as precursor needs a substrate temperature higher than $320^{\circ} \mathrm{C}$ in order to promote crystallization and realize high carrier mobility 


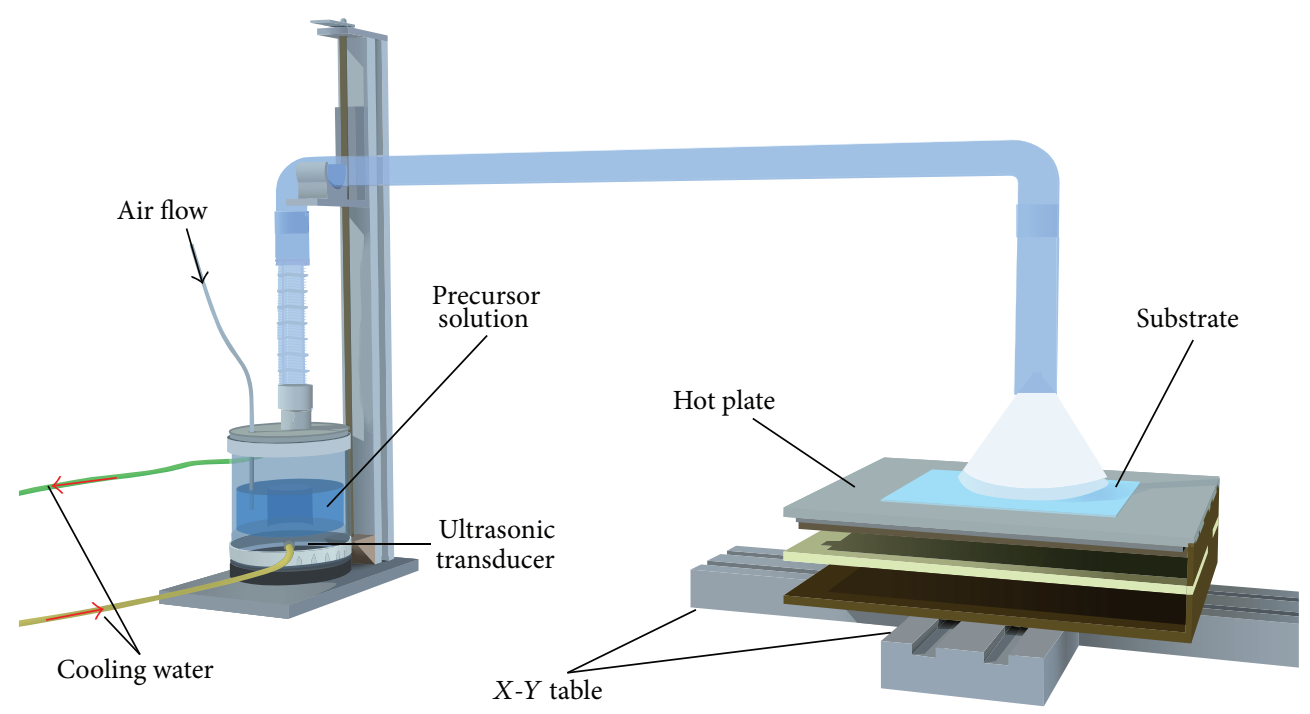

FIGURE 1: Schematic of ultrasonic spray apparatus.

and transmittance [16, 17]. ZnO films prepared by spray pyrolysis with various precursors have been investigated previously. With ZnO ETLs prepared by spray pyrolysis from 2-methoxyethanol diluted sol-gel precursor at $250-300^{\circ} \mathrm{C}$, P3HT:PCBM based PSCs had relative high performance [18], achieving PCEs of roughly 2.99-3.22\%. Unfortunately, PSC devices with $\mathrm{ZnO}$ ETL prepared at $150^{\circ} \mathrm{C}$ exhibited a poor PCE of only $0.94 \%$. Although $\mathrm{ZnO}$ films have been prepared on flexible substrates at $100^{\circ} \mathrm{C}$ using spray pyrolysis with diethylzinc (DEZ) solution $[19,20]$, DEZ reacts violently with water and easily ignites upon contact with air. The toxicity and instability of DEZ leads to serious security problems to both operators and the environment, limiting its use in potential applications.

Here we have developed an ultrasonic spray pyrolysis (USP) technique in order to prepare highly dense $\mathrm{ZnO}$ thin films using zinc-ammonia $\left[\left(\mathrm{Zn}\left(\mathrm{NH}_{3}\right)_{4}\right](\mathrm{OH})_{2}\right.$ solution as a precursor, which can be decomposed to the three components, $\mathrm{ZnO}, \mathrm{NH}_{3}$, and $\mathrm{H}_{2} \mathrm{O}$. The preparation of the $\mathrm{ZnO}$ films described here is extremely simple and cost-effective with a low temperature process under ambient conditions. Compared with the sol-gel approach, the whole process does not require an anneal and does not use any toxic organic solvents. In this study we show the thermal effect of the substrate temperature upon surface morphology, structure, optical transparency, and performance of $\mathrm{ZnO}$ based inverted PSCs.

\section{Experimental}

Zinc acetate $\left(\mathrm{Zn}\left(\mathrm{CH}_{3} \mathrm{COO}\right)_{2} \cdot 2 \mathrm{H}_{2} \mathrm{O}\right)$ and ammonia water $\left(\mathrm{NH}_{3} \cdot \mathrm{H}_{2} \mathrm{O}\right.$, 25 28\%) were purchased from Shanghai Chemical Reagent Corp., China (analytical grade reagents), and used as received. P3HT and PCBM were purchased from Lumtec, Taiwan. The precursor solution was prepared using the following recipe. Zinc acetate $(5 \mathrm{~g})$ was dissolved

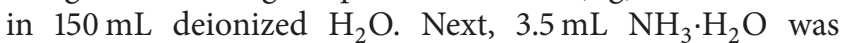
dropped into the solution whilst magnetically stirring. After the solution had completely precipitated, the mixture was vacuum-filtrated and washed by more than $1 \mathrm{~L}$ of deionized water in order to remove $\mathrm{CH}_{3} \mathrm{COO}^{-}$. Finally, the precipitate was dissolved using $50 \mathrm{~mL}$ of ammonia-water and then diluted with $300 \mathrm{~mL}$ deionized water.

$\mathrm{ZnO}$ films were fabricated by using an ultrasonic spray pyrolysis apparatus developed in-house. This consists of a cylindrical ultrasonic transducer, an automatic $X-Y$ table, a $400 \times 300 \mathrm{~mm}^{2}$ temperature controlled heating block, a $15 \mathrm{~mm}$ diameter dropping-proof quartz nozzle, and pipe fittings, as shown in Figure 1. The nozzle was mounted above the heating block. In this study, the deposition of $\mathrm{ZnO}$ films upon ITO glass $(6.7 \Omega / \mathrm{sq})$, soda lime glass, and PET was investigated. All substrates were consecutively cleaned in an ultrasonic bath containing detergent, acetone, deionized water, and ethanol for each 10 min step and then dried with nitrogen $[21,22]$. During the deposition process, compressed air was used as a carrier gas. The spray rate was held constant at $10 \mathrm{~L} / \mathrm{min}$. The distance between the nozzle and substrate was kept at $10 \mathrm{~mm}$, which was chosen to ensure that the mist reached the substrate for a given flow rate. $\mathrm{ZnO}$ thin films were deposited at substrate temperatures of $125^{\circ} \mathrm{C}, 150^{\circ} \mathrm{C}$, $200^{\circ} \mathrm{C}$, and $250^{\circ} \mathrm{C}$, respectively.

$\mathrm{ZnO}$ films were characterized before device fabrication. The composition and electron structure were tested by using $\mathrm{X}$-ray photoelectron spectroscopy (XPS, Thermo ESCALAB). The crystal structure was determined by using $\mathrm{X}$-ray diffraction (XRD, PANalytical X'Pert PRO) in grazing incidence mode with a $\mathrm{Cu} \mathrm{K}$ radiation $(0.154 \mathrm{~nm})$. The surface morphology of the films was characterized by using an atomic force microscope (AFM, Dimension Edge). The optical properties of $\mathrm{ZnO}$ films deposited on glass substrates were studied by measuring the optical transmittance spectra in the wavelength range $250-850 \mathrm{~nm}$, with a UV-visible spectrophotometer (Hitachi U-3900). The thickness of all films was measured using a stylus profile meter (Alpha-Step D-100). 


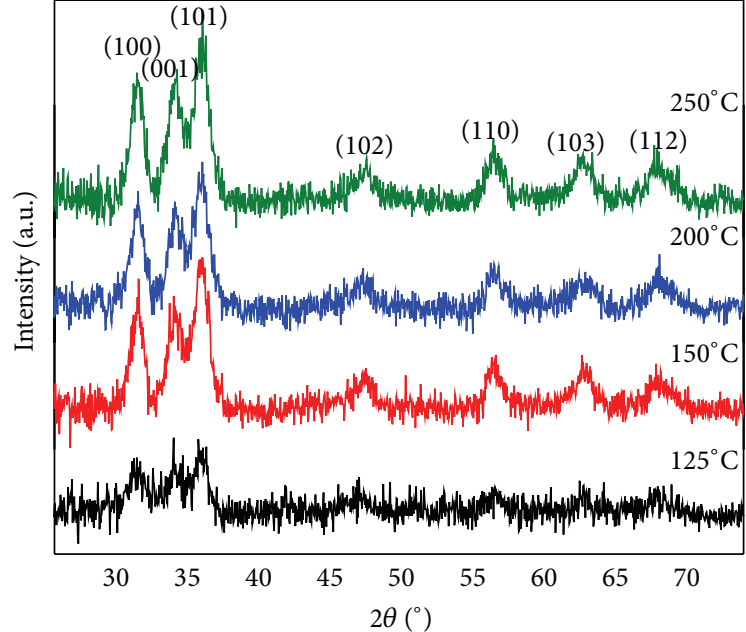

FIGURE 2: X-ray diffraction patterns of $\mathrm{ZnO}$ films grown on ITO glass at different temperatures.

To investigate the performance of $\mathrm{ZnO}$ ETLs in PSC devices, inverted PSCs with stack structure of ITO/ZnO/ P3HT:PCBM/ $\mathrm{MoO}_{x} / \mathrm{Ag}$ were fabricated. For the active layer, a blend of P3HT and PCBM film in a 1:1 weight ratio up to about $200 \mathrm{~nm}$ was spin-coated on the $\mathrm{ZnO}$ film at $1000 \mathrm{rpm}$ for $16 \mathrm{~s} . \mathrm{MoO}_{x}$ films $(15 \mathrm{~nm})$ and $\mathrm{Ag}$ films $(100 \mathrm{~nm})$ were then successively thermally evaporated onto the P3HT:PCBM blend at $10^{-4} \mathrm{~Pa}$. Current density-voltage $(J-V)$ characteristics were measured with a Keithley 2400 under a xenon lamp with an illumination power of $100 \mathrm{~mW} / \mathrm{cm}^{2}$. All measurements were performed in air at $25^{\circ} \mathrm{C}$.

\section{Results and Discussion}

To investigate the effect of thermal treatment upon the crystal structure of $\mathrm{ZnO}$, films were fabricated at different temperatures with thickness of $\sim 200 \mathrm{~nm}$ on ITO glass. XRD patterns of the $\mathrm{ZnO}$ films prepared at $125^{\circ} \mathrm{C}, 150^{\circ} \mathrm{C}, 200^{\circ} \mathrm{C}$, and $250^{\circ} \mathrm{C}$ are shown in Figure 2. All of the samples exhibit a wurtzite $\mathrm{ZnO}$ structure compared with standard PDF card (number 361451). Three typical peaks occur at $31.8^{\circ}, 34.3^{\circ}$, and $56.6^{\circ}$ which correspond to (100), (002), and (101) directions, reflecting nonoriented polycrystalline $\mathrm{ZnO}$ thin films, which were different with single-crystalline $\mathrm{ZnO}$ films grown at the $800^{\circ} \mathrm{C}$ high temperature and a lower growth rate by the similar mist chemical vapor deposition technique [23]. Figure 2 shows that the crystal structure of the $\mathrm{ZnO}$ films was modified by thermal effects. The sample prepared at $125^{\circ} \mathrm{C}$ exhibited weak diffraction peaks which indicates poor crystal structure. For samples with substrate temperature of $150^{\circ} \mathrm{C}, 200^{\circ} \mathrm{C}$, and $250^{\circ} \mathrm{C}$, the intensity of diffraction peaks was almost the same. It indicates that $\mathrm{ZnO}$ films tend to form a stable crystal structure at the substrate temperature above $150^{\circ} \mathrm{C}$. Although $\mathrm{ZnO}$ films deposited at $180^{\circ} \mathrm{C}$ using zinc acetate solution have been previously reported [24], however, $\mathrm{X}$-ray diffraction results showed that all these samples seemed to be amorphous $\mathrm{ZnO}$. From the discussion above, it is feasible to deposit $\mathrm{ZnO}$ films with good crystal structure upon ITO glass or flexible substrate such as an ETL of PSCs.

The thermal effect upon electron structure was characterized by XPS. Before testing, $\mathrm{ZnO}$ films were etched using an argon plasma for approximately $10 \mathrm{~nm}$. Figure 3 shows core level XPS spectra of $\mathrm{Zn} 2 \mathrm{p}$ and $\mathrm{O}$ 1s for the $\mathrm{ZnO}$ films that were not annealed. From Figure 3(a), it can be seen that the binding energy of the $\mathrm{Zn} 2 \mathrm{p} \mathrm{3/2}$ peak was at $1021.8 \mathrm{eV}$ in the $\mathrm{ZnO}$ film prepared at $125^{\circ} \mathrm{C}$. The maximum of the $\mathrm{Zn}$ 2 p $3 / 2$ peak shifts toward higher binding energy by $0.8 \mathrm{eV}$ as the substrate temperature increases to $150^{\circ} \mathrm{C}$. This shift implies that less $\mathrm{Zn}$ atoms are bound to $\mathrm{O}$ atoms [12]. A further increase of the substrate temperature leads to the $\mathrm{Zn}$ 2 p 3/2 peak shifting towards higher binding energies. This indicates that the oxygen-deficient component had decreased and the number of $\mathrm{Zn}-\mathrm{O}$ bonds in the films had increased by higher substrate temperature. The $\mathrm{O}$ 1s XPS spectra exhibit asymmetric line shapes (Figure 3(b)). The peak with lower binding (529.8 to 530.4) energy corresponds to $\mathrm{O}$ atoms in a $\mathrm{ZnO}$ matrix. The second peak at 531.7 to $531.9 \mathrm{eV}$ is probably due to $\mathrm{Zn}(\mathrm{OH})_{2}[25,26]$. The relative magnitude of the low binding energy $\mathrm{O}$ atoms was $64 \%$ when the substrate temperature is $125^{\circ} \mathrm{C}$ and this increased to $71 \%$ after the substrate temperature was increased to $250^{\circ} \mathrm{C}$. It can therefore be seen that a higher substrate temperature increases the number of $\mathrm{Zn}-\mathrm{O}$ bonds in $\mathrm{ZnO}$ films.

The thermal effect upon morphology in $\mathrm{ZnO}$ films was investigated by using AFM. All samples were scanned over an area of of $1 \times 1 \mu \mathrm{m}^{2}$. AFM 3D morphology images of samples prepared at $125^{\circ} \mathrm{C}, 150^{\circ} \mathrm{C}, 200^{\circ} \mathrm{C}$, and $250^{\circ} \mathrm{C}$ are shown in Figure 4 . The film prepared at $125^{\circ} \mathrm{C}$ exhibited a suedelike textured surface. The trichomes on the surface become thinner when the substrate temperature was increased to $150^{\circ} \mathrm{C}$. A further increase of the substrate temperature to $200^{\circ} \mathrm{C}$ and $250^{\circ} \mathrm{C}$ leads to the observation of spherical grains upon the film surface. This is typically produced by fast nucleation and growth rate [27]. The thermal effect induced morphology also leads to varying roughness. The root mean square (RMS) roughness values were $1.95 \mathrm{~nm}, 2.25 \mathrm{~nm}, 3.71$, and $4.85 \mathrm{~nm}$ for $\mathrm{ZnO}$ films prepared at $125^{\circ} \mathrm{C}, 150^{\circ} \mathrm{C}, 200^{\circ} \mathrm{C}$, and $250^{\circ} \mathrm{C}$, respectively. Notice that grains on the surface of the $\mathrm{ZnO}$ films prepared at lower substrate temperature were smaller and more uniform than those prepared at higher substrate temperature. Thus, the ideal substrate temperature in this study for high performance ZnO ETL fabrication should be lower than $250^{\circ} \mathrm{C}$.

To investigate the thermal effect upon optical performance of $\mathrm{ZnO}$ films, several samples with the thickness of $\sim 100 \mathrm{~nm}$ were prepared at different substrate temperatures and tested. Figure 5 Shows the optical transmittance spectra of $\mathrm{ZnO}$ films prepared at $125^{\circ} \mathrm{C}, 150^{\circ} \mathrm{C}, 200^{\circ} \mathrm{C}$, and $250^{\circ} \mathrm{C}$. The film prepared at the low temperature of $125^{\circ} \mathrm{C}$ had a lower optical transmittance due to the poor crystal structure. The rest of the films prepared at higher temperature have a greater transmittance in the range of $400-850 \mathrm{~nm}$ with a value of up to $83 \%$ when compared to air. $\mathrm{ZnO}$ films prepared at higher temperature exhibit an obvious absorption onset red-shift at approximately $350 \mathrm{~nm}$. The shift is due to 
TABLE 1: Device characteristics of PSCs prepared at different substrate temperatures.

\begin{tabular}{|c|c|c|c|c|c|c|c|}
\hline $\begin{array}{l}\mathrm{ZnO} \text { substrate } \\
\text { temperature }\left({ }^{\circ} \mathrm{C}\right)\end{array}$ & $\begin{array}{l}\text { Thickness } \\
(\mathrm{nm})\end{array}$ & $\begin{array}{r}V_{\mathrm{OC}} \\
(\mathrm{V})\end{array}$ & $\begin{array}{c}J_{\mathrm{SC}} \\
\left(\mathrm{mA} / \mathrm{cm}^{2}\right)\end{array}$ & $\begin{array}{l}\mathrm{FF} \\
(\%)\end{array}$ & $\begin{array}{r}\text { PCE } \\
(\%) \\
\end{array}$ & $\begin{array}{c}R_{S} \\
\Omega \mathrm{cm}^{2}\end{array}$ & $\begin{array}{c}R_{\mathrm{SH}} \\
\Omega \mathrm{cm}^{2} \\
\end{array}$ \\
\hline 125 & 50 & 0.56 & 6.74 & 43.47 & 1.64 & 28 & 277 \\
\hline 150 & 50 & 0.60 & 8.92 & 47.89 & 2.55 & 14 & 269 \\
\hline 200 & 50 & 0.61 & 9.26 & 53.63 & 3.05 & 13 & 454 \\
\hline 250 & 50 & 0.62 & 8.83 & 50.34 & 2.75 & 15 & 420 \\
\hline 300 & 50 & 0.62 & 7.85 & 51.81 & 2.56 & 18 & 370 \\
\hline Sol-gel & 50 & 0.62 & 9.37 & 55.74 & 3.23 & 13 & 769 \\
\hline
\end{tabular}

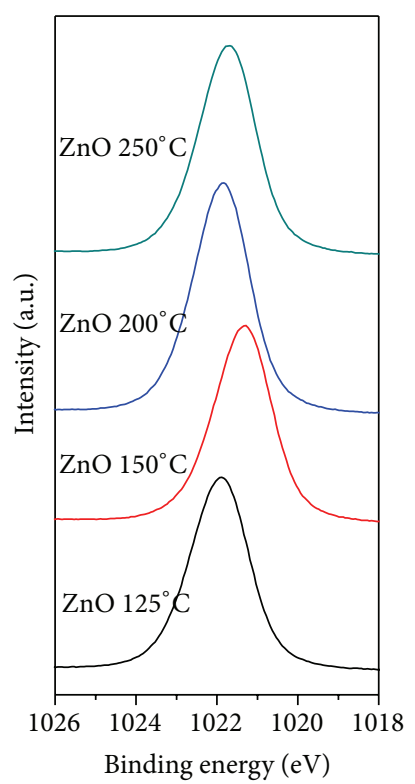

(a) $\mathrm{Zn} 2 \mathrm{p}$

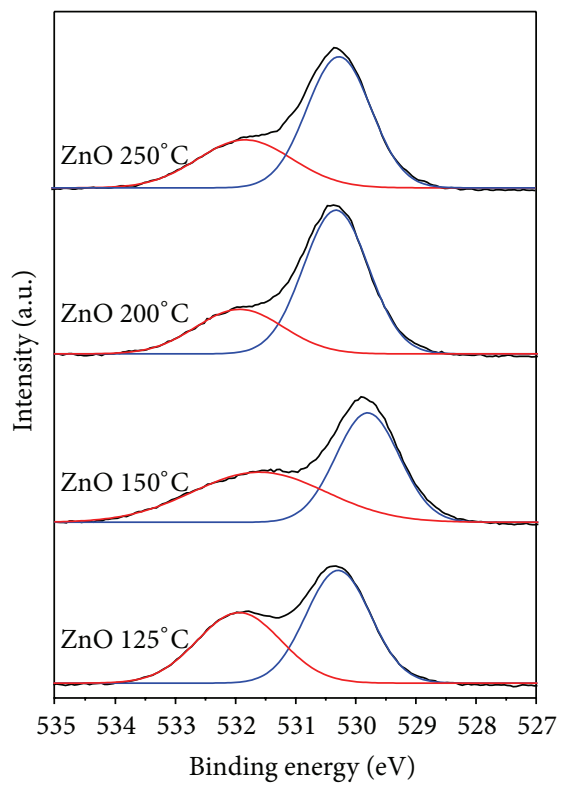

(b) $\mathrm{O} 1 \mathrm{~s}$

Figure 3: (a) Zn 2p and (b) O 1s XPS spectra of $\mathrm{ZnO}$ films fabricated with different substrate temperatures.

the narrower energy gap of $\mathrm{ZnO}$ films that were prepared at higher substrate temperature. The energy gap of the $\mathrm{ZnO}$ film prepared at $125^{\circ} \mathrm{C}$ was $3.27 \mathrm{eV}$, while it shifted to $3.22 \mathrm{eV}$ when the substrate temperature increased up to $250^{\circ} \mathrm{C}$.

The effect of temperature upon $\mathrm{ZnO}$ films of different thicknesses in inverted PSC devices was investigated in this study. $J-V$ characteristics of the inverted PSC devices with $\mathrm{ZnO}$ ETLs prepared at different temperature are shown in Figure 6. The performances of the inverted PSCs are summarized in Table 1.

For the device with $\mathrm{ZnO}$ ETLs deposited at $125^{\circ} \mathrm{C}$, the PCE was only $1.64 \%$ with an open circuit voltage $\left(V_{\mathrm{OC}}\right)$ of $0.56 \mathrm{~V}$, a short circuit current density $\left(J_{\mathrm{SC}}\right)$ of $9.64 \mathrm{~mA} / \mathrm{cm}^{2}$, and a fill factor (FF) of $43.47 \%$. The device had a relatively high series resistance $\left(R_{S}\right)$ and a low shunt resistance $\left(R_{\mathrm{SH}}\right)$. We propose that the poor performance was caused by low light transmittance and conductivity that is attributed to poor surface morphology and amorphous structure as demonstrated by AFM and XRD data. When the substrate temperature was increased to $200^{\circ} \mathrm{C}$, the best device performance was obtained, where the PCE was $3.05 \%$ with $V_{\mathrm{OC}}$ of $0.61 \mathrm{~V}, J_{\mathrm{SC}}$ of $9.26 \mathrm{~mA} / \mathrm{cm}^{2}$, and $\mathrm{FF}$ of $53.63 \%$. The devices with $\mathrm{ZnO}$ ETL prepared at $250^{\circ} \mathrm{C}$ and $300^{\circ} \mathrm{C}$ showed gradual degradation of $J_{\mathrm{SC}}, \mathrm{FF}$, and PCE. The degradation might be caused by the rough surface morphology of ZnO ETLs.

$J-V$ characteristics of the inverted PSC performance with $\mathrm{ZnO}$ ETLs of different thickness are shown in Figure 7. Table 2 is the summary of the device performance. For all devices with ZnO ETLs, both $V_{\mathrm{OC}}$ and $J_{\mathrm{SC}}$ were improved when compared to devices without $\mathrm{ZnO}$. This indicates that $\mathrm{ZnO}$ can effectively modify the work function of ITO for electron transport and collection. PSC devices with $50 \mathrm{~nm}$ $\mathrm{ZnO}$ ETL showed the highest PCE. For the devices with a $25 \mathrm{~nm} \mathrm{ZnO}$ ETL, the PCE was $2.75 \%$ with $V_{\mathrm{OC}}$ of $0.59 \mathrm{~V}$, $J_{\mathrm{SC}}$ of $9.64 \mathrm{~mA} / \mathrm{cm}^{2}$, and $\mathrm{FF}$ of $48.11 \%$. When the thickness of $\mathrm{ZnO}$ ETL was increased, the performance of the device decreased gradually. For the device with a $100 \mathrm{~nm} \mathrm{ZnO}$ ETL, the PCE was $2.58 \%$ with low $J_{\mathrm{SC}}$ of $8.64 \mathrm{~mA} / \mathrm{cm}^{2}$.

The general function of ETLs is to select negative carriers and block positive carriers to the cathode in a charge collection process and thus to increase $R_{\mathrm{SH}}$ of PSCs $[7,8,28]$. The performance of $\mathrm{ZnO}$ films and PSC devices discussed above demonstrated that crystal structure and composition of ZnO ETLs induced by a thermal effect are essential in 
TABLE 2: Device characteristics of PSCs prepared at different substrate temperatures.

\begin{tabular}{lcccccc}
\hline $\begin{array}{l}\text { ZnO substrate } \\
\text { temperature }\left({ }^{\circ} \mathrm{C}\right)\end{array}$ & $\begin{array}{c}\text { Thickness } \\
(\mathrm{nm})\end{array}$ & $\begin{array}{c}V_{\mathrm{OC}} \\
(\mathrm{V})\end{array}$ & $\begin{array}{c}J_{\mathrm{SC}} \\
\left(\mathrm{mA} / \mathrm{cm}^{2}\right)\end{array}$ & $\begin{array}{c}\text { FF } \\
(\%)\end{array}$ & $\begin{array}{c}\text { PCE } \\
(\%)\end{array}$ & $\begin{array}{c}R_{S} \\
\Omega \mathrm{cm}^{2}\end{array}$ \\
\hline 200 & 0 & 0.25 & 5.49 & 28.36 & 0.40 & 361 \\
200 & 25 & 0.59 & 9.64 & 48.11 & 2.75 & 16 \\
200 & 50 & 0.61 & 9.26 & 53.63 & 3.05 & 357 \\
200 & 75 & 0.62 & 9.18 & 52.21 & 2.96 & 13 \\
200 & 100 & 0.61 & 8.64 & 48.63 & 2.58 & 15 \\
\hline
\end{tabular}

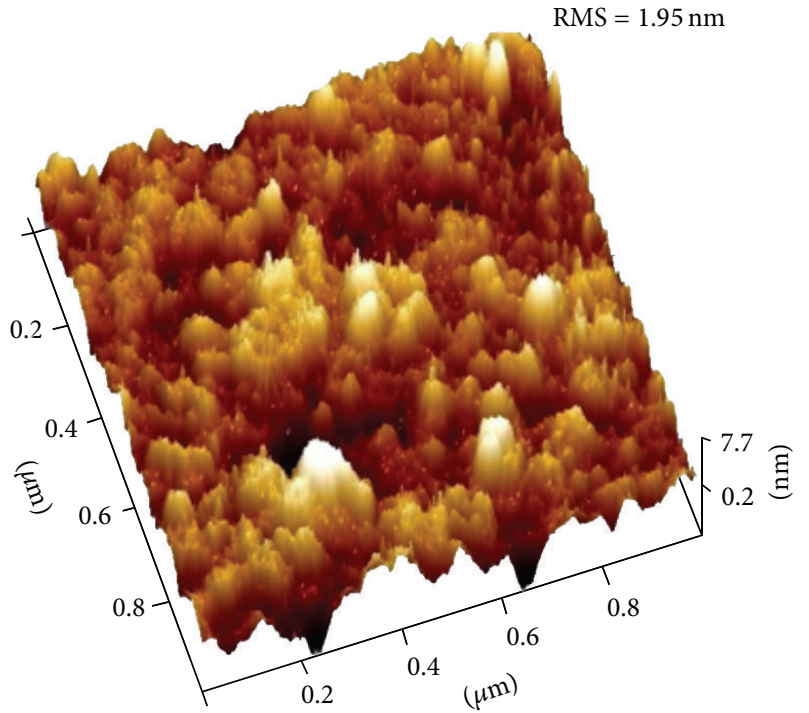

(a)

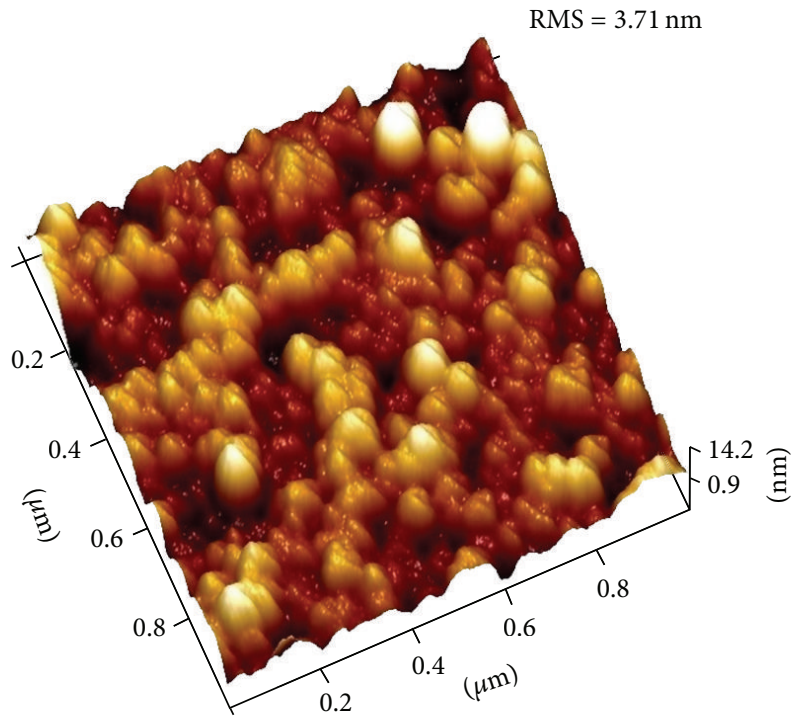

(c)

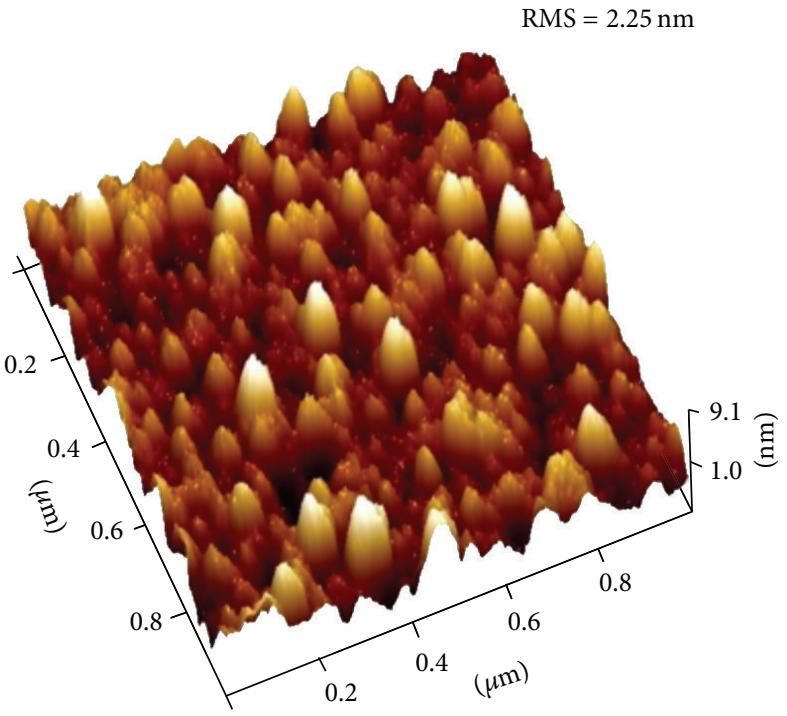

(b)

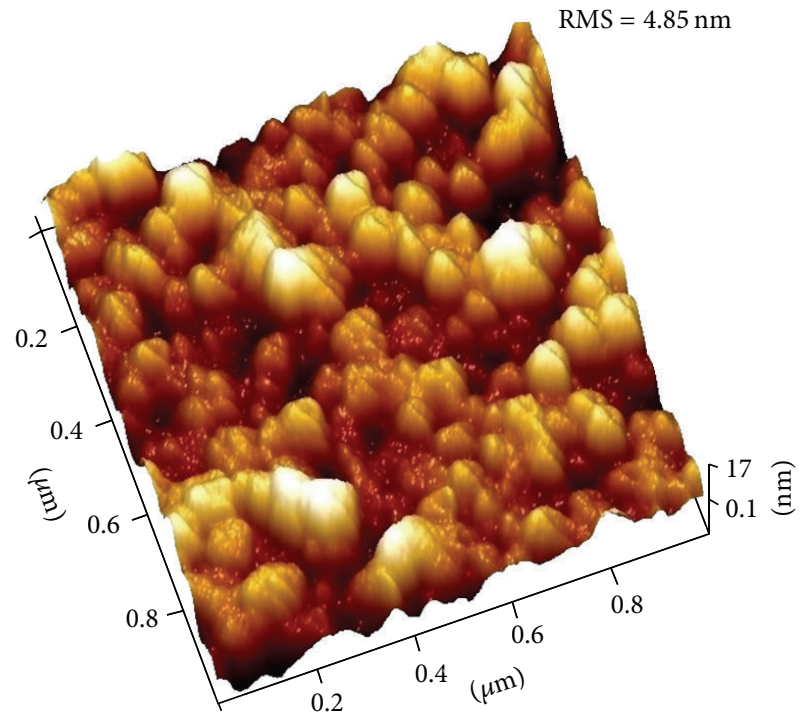

(d)

FIGURE 4: 3D AFM morphology images of $\mathrm{ZnO}$ films on ITO glass and grown at different temperatures. (a) $125^{\circ} \mathrm{C}$, (b) $150^{\circ} \mathrm{C}$, (c) $200^{\circ} \mathrm{C}$, and (d) $250^{\circ} \mathrm{C}$.

light harvesting. Furthermore the thermal effect leads to a decreasing exaction recombination by influencing the optical performance and electron structure related energy level. Fortunately, the low temperature spray pyrolysis method requires quite a low temperature $\left(\sim 150^{\circ} \mathrm{C}\right)$ and is therefore compatible with flexible PSCs fabrication. A higher substrate temperature provided a more perfect crystal structure for $\mathrm{ZnO}$ ETLs. However, this also increases the roughness of $\mathrm{ZnO}$ films by making grains larger as shown in the AFM images. Although we have no clear evidence, we presume 


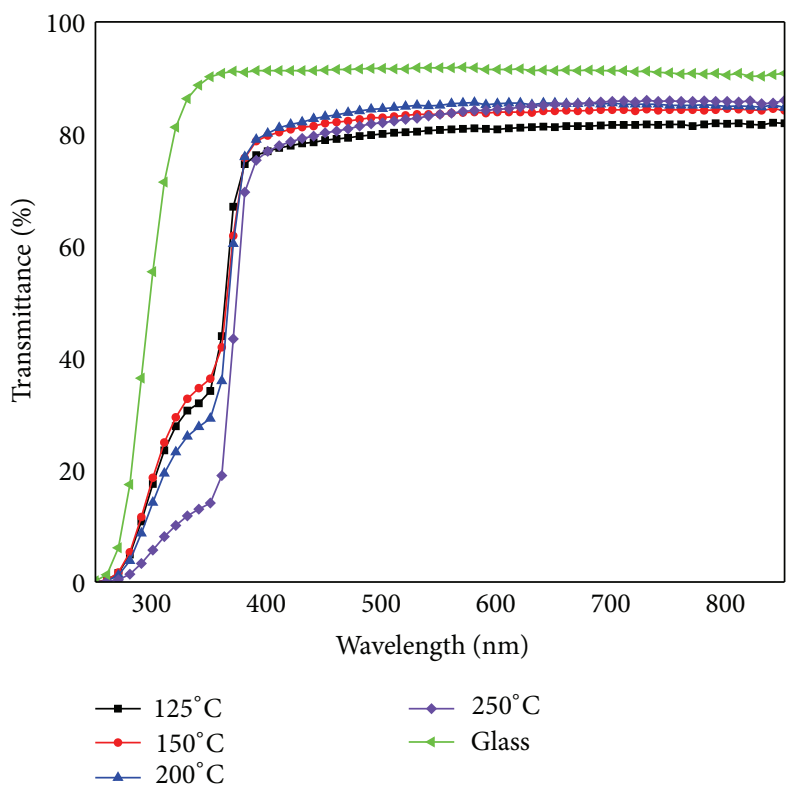

FIgURE 5: The transmittance spectra of $\mathrm{ZnO}$ films fabricated with different substrate temperature.

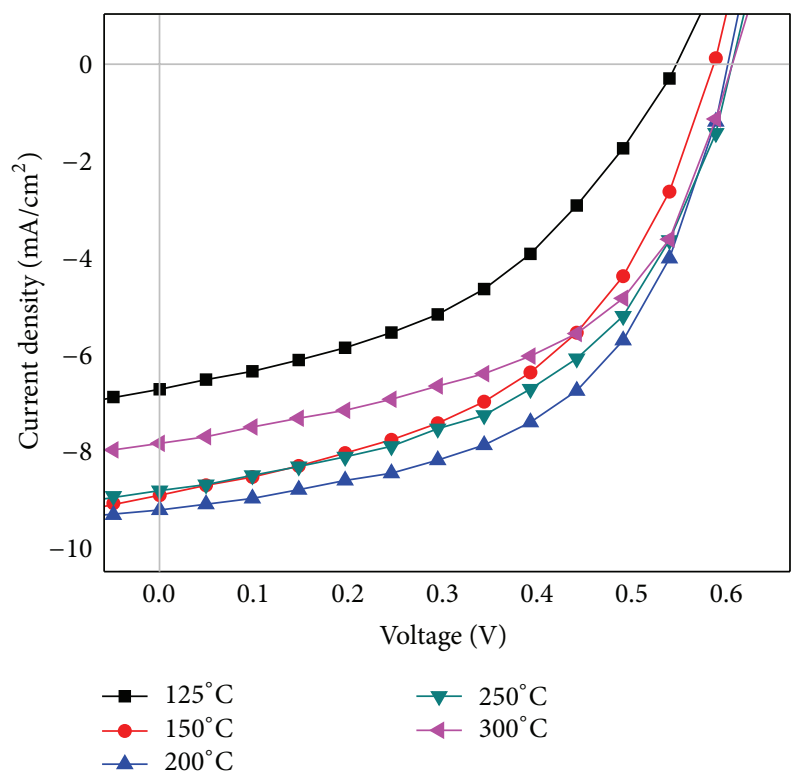

FIgURE 6: $J-V$ characteristics of devices with ZnO ETLs prepared at different substrate temperatures.

that coarse grains of different sizes on the ZnO ETL surface induce serious interfacial problems between ETL and the spin-coated active layer. This leads to the charge transport channel between the active layer and the ZnO ETL becoming narrow. Thus, $R_{S}$ is increased by the degradation of electron collection efficiency. Incidentally, the interfacial problem may not exist or become a tiny problem when the active layer was prepared by spray coating or printing. $J_{\mathrm{SC}}$ also decreased gradually as the thickness of ZnO ETLs increased, while $V_{\mathrm{OC}}$ remained stable. This indicates that contact resistance of $\mathrm{ZnO}$ ETLs is sensitive to thickness. Thin ZnO ETL with low $R_{S}$ is

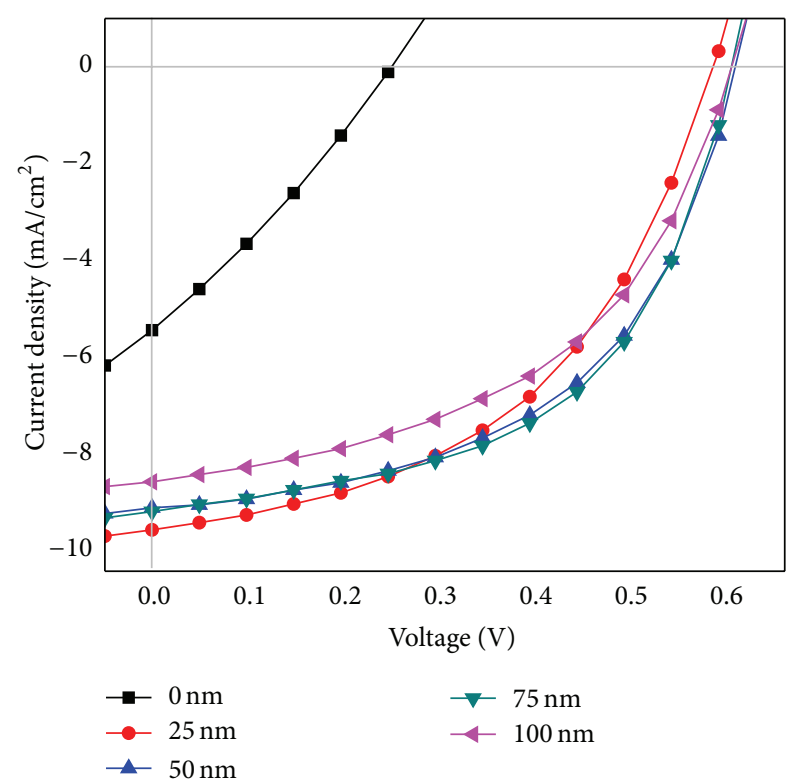

FIgURE 7: $J-V$ characteristics of devices with ZnO ETLs prepared with different thicknesses.

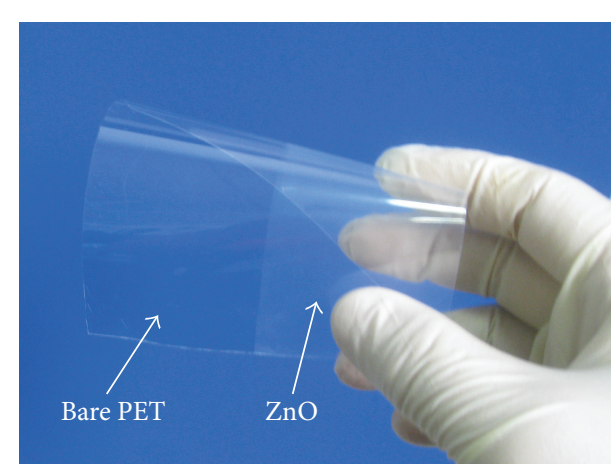

FIGURE 8: A photograph of a $\mathrm{ZnO}$ film prepared on a flexible PET substrate.

beneficial for efficient PSC, unless it is not thick enough to cover the entire range of the active layer. This investigation suggests that a suitable thickness of ZnO ETL prepared by this spray pyrolysis method is approximately $50 \mathrm{~nm}$.

Compared to PSC devices with spin-coated ZnO ETL, PSCs with ZnO ETLs prepared by this technique have relatively low FF and PCE. This might be attributed to the microscopic rough surface with coffee rings that induces serious contact problems between the spin-coated active layer and ETLs [18]. Practically, the spin-coating approach is generally suitable for lab-scale fabrication of $\mathrm{ZnO}$ and devices. However, the use of this low temperature spray pyrolysis technique means that $\mathrm{ZnO}$ films can be processed upon a flexible substrate without annealing and with good thickness control. Additionally, this is compatible with fabrication of commercial PSCs using low-cost production methods like the well-known roll-to-roll process. Figure 8 shows a $\mathrm{ZnO} / \mathrm{PET}$ film sample prepared at $150^{\circ} \mathrm{C}$. In our next work, 
flexible PSCs with ZnO ETLs prepared by this technique will be discussed in detail.

\section{Conclusion}

High-quality $\mathrm{ZnO}$ films were successfully processed by low temperature spray pyrolysis using a $\left[\left(\mathrm{Zn}\left(\mathrm{NH}_{3}\right)_{4}\right](\mathrm{OH})_{2}\right.$ solution at a low temperature of $150^{\circ} \mathrm{C}$. The substrate temperature and the thickness of $\mathrm{ZnO}$ films had some influences on the composition, crystal structure, and optical transmittance as well as the performance of inverted PSCs. The optimized PCE of the PSCs based on $\mathrm{ZnO}$ ETLs prepared at $200^{\circ} \mathrm{C}$ with the thickness of $50 \mathrm{~nm}$ reached a maximum of 3.05\%. In addition, this technique is quite easy and low-cost, and it is compatible with the roll-to-roll production of large-scale flexible PSCs.

\section{Conflict of Interests}

The authors declare that there is no conflict of interests regarding the publication of this paper.

\section{Acknowledgments}

This work was supported by Co-Innovation Center for Micro/Nano Optoelectronic Materials and Devices, Technology Project from Chongqing Education Committee (Grant no. KJ1401113), the Chongqing Science \& Technology Commission (Grant no. cstc2013jcyjys50001), and Chongqing University of Science and Arts (Grants nos. R2012CJ18 and Z2013CJ02).

\section{References}

[1] T. Yang, W. Cai, D. Qin et al., "Solution-processed zinc oxide thin film as a buffer layer for polymer solar cells with an inverted device structure," Journal of Physical Chemistry C, vol. 114, no. 14, pp. 6849-6853, 2010.

[2] J. E. Carlé, T. R. Andersen, M. Helgesen, E. Bundgaard, M. Jorgensen, and F. C. Krebs, "A laboratory scale approach to polymer solar cells using one coating/printing machine, flexible substrates, no ITO, no vacuum and no spincoating," Solar Energy Materials and Solar Cells, vol. 108, pp. 126-128, 2013.

[3] D. J. Lipomi, B. C.-K. Tee, M. Vosgueritchian, and Z. Bao, "Stretchable organic solar cells," Advanced Materials, vol. 23, no. 15, pp. 1771-1775, 2011.

[4] Z. He, C. Zhong, S. Su, M. Xu, H. Wu, and Y. Cao, "Enhanced power-conversion efficiency in polymer solar cells using an inverted device structure," Nature Photonics, vol. 6, no. 9, pp. 591-595, 2012.

[5] L. Chen, P. Wang, F. Li, S. Yu, and Y. Chen, "Efficient bulk heterojunction polymer solar cells using PEDOT/PSS doped with solution-processed $\mathrm{MoO}_{3}$ as anode buffer layer," Solar Energy Materials and Solar Cells, vol. 102, pp. 66-70, 2012.

[6] S. Chen, J. R. Manders, S.-W. Tsang, and F. So, "Metal oxides for interface engineering in polymer solar cells," Journal of Materials Chemistry, vol. 22, no. 46, pp. 24202-24212, 2012.

[7] R. Po, C. Carbonera, A. Bernardi, and N. Camaioni, "The role of buffer layers in polymer solar cells," Energy \& Environmental Science, vol. 4, no. 2, pp. 285-310, 2011.
[8] L. K. Jagadamma, M. Abdelsamie, A. El Labban et al., "Efficient inverted bulk-heterojunction solar cells from low-temperature processing of amorphous $\mathrm{ZnO}$ buffer layers," Journal of Materials Chemistry A, vol. 2, no. 33, pp. 13321-13331, 2014.

[9] C.-C. Chen, W.-H. Chang, K. Yoshimura et al., "An efficient triple-junction polymer solar cell having a power conversion efficiency exceeding 11\%," Advanced Materials, vol. 26, no. 32, pp. 5670-5677, 2014.

[10] H.-Y. Park, D. Lim, K.-D. Kim, and S.-Y. Jang, "Performance optimization of low-temperature-annealed solutionprocessable $\mathrm{ZnO}$ buffer layers for inverted polymer solar cells," Journal of Materials Chemistry A, vol. 1, no. 21, pp. 6327-6334, 2013.

[11] Y. Jouane, S. Colis, G. Schmerber et al., "Annealing treatment for restoring and controlling the interface morphology of organic photovoltaic cells with interfacial sputtered $\mathrm{ZnO}$ films on P3HT:PCBM active layers," Journal of Materials Chemistry, vol. 22, no. 4, pp. 1606-1612, 2012.

[12] Y. Sun, J. H. Seo, C. J. Takacs, J. Seifter, and A. J. Heeger, "Inverted polymer solar cells integrated with a lowtemperature-annealed sol-gel-derived $\mathrm{ZnO}$ film as an electron transport layer," Advanced Materials, vol. 23, no. 14, pp. 1679-1683, 2011.

[13] R. Ayouchi, D. Leinen, F. Martín, M. Gabas, E. Dalchiele, and J. R. Ramos-Barrado, "Preparation and characterization of transparent $\mathrm{ZnO}$ thin films obtained by spray pyrolysis," Thin Solid Films, vol. 426, no. 1-2, pp. 68-77, 2003.

[14] G. Adamopoulos, A. Bashir, W. P. Gillin et al., "Structural and electrical characterization of $\mathrm{ZnO}$ films grown by spray pyrolysis and their application in thin-film transistors," Advanced Functional Materials, vol. 21, no. 3, pp. 525-531, 2011.

[15] S. Sali, M. Boumaour, M. Kechouane, S. Kermadi, and F. Aitamar, "Nanocrystalline $\mathrm{ZnO}$ film deposited by ultrasonic spray on textured silicon substrate as an anti-reflection coating layer," Physica B: Condensed Matter, vol. 407, no. 13, pp. 26262631, 2012.

[16] T. P. Rao, M. C. S. Kumar, A. Safarulla, V. Ganesan, S. R. Barman, and C. Sanjeeviraja, "Physical properties of $\mathrm{ZnO}$ thin films deposited at various substrate temperatures using spray pyrolysis," Physica B: Condensed Matter, vol. 405, no. 9, pp. 2226-2231, 2010.

[17] S. A. Studenikin, N. Golego, and M. Cocivera, "Optical and electrical properties of undoped $\mathrm{ZnO}$ films grown by spray pyrolysis of zinc nitrate solution," Journal of Applied Physics, vol. 83, no. 4, pp. 2104-2111, 1998.

[18] Y.-J. Noh, S.-I. Na, and S.-S. Kim, "Inverted polymer solar cells including $\mathrm{ZnO}$ electron transport layer fabricated by facile spray pyrolysis," Solar Energy Materials \& Solar Cells, vol. 117, pp. 139144,2013

[19] K. Yoshino, Y. Takemoto, M. Oshima et al., "Low-temperature growth of $\mathrm{ZnO}$ films by spray pyrolysis," Japanese Journal of Applied Physics, vol. 50, p. 207, 2011.

[20] Y. Takemoto, M. Oshima, K. Yoshino et al., "Low sheet resistivity of transparent $\mathrm{Ga}$-doped $\mathrm{ZnO}$ film grown by atmospheric spray pyrolysis," Japanese Journal of Applied Physics, vol. 50, no. 8, Article ID 088001, 2011.

[21] Y. Zheng, R. Wu, W. Shi, Z. Guan, and J. Yu, "Effect of in situ annealing on the performance of spray coated polymer solar cells," Solar Energy Materials \& Solar Cells, vol. 111, pp. 200-205, 2013.

[22] F. Li, Y. Du, Y. Chen, L. Chen, J. Zhao, and P. Wang, "Direct application of P3HT-DOPO@ZnO nanocomposites in hybrid 
bulk heterojunction solar cells via grafting $\mathrm{P} 3 \mathrm{HT}$ onto $\mathrm{ZnO}$ nanoparticles," Solar Energy Materials \& Solar Cells, vol. 97, pp. 64-70, 2012.

[23] T. Kawaharamura, H. Nishinaka, and S. Fujita, "Growth of crystalline zinc oxide thin films by fine-channel-mist chemical vapor deposition," Japanese Journal of Applied Physics, vol. 47, no. 6, pp. 4669-4675, 2008.

[24] H. Nishinara, T. Kawaharamura, and S. Fujita, "Low-temperature growth of $\mathrm{ZnO}$ thin films by linear source ultrasonic spray chemical vapor deposition," Japanese Journal of Applied Physics, vol. 46, no. 10, pp. 6811-6813, 2007.

[25] Y. Zhang, G. Du, D. Liu et al., "Crystal growth of undoped $\mathrm{ZnO}$ films on Si substrates under different sputtering conditions," Journal of Crystal Growth, vol. 243, no. 3-4, pp. 439-443, 2002.

[26] X. Q. Wei, B. Y. Man, M. Liu, C. S. Xue, H. Z. Zhuang, and C. Yang, "Blue luminescent centers and microstructural evaluation by XPS and Raman in $\mathrm{ZnO}$ thin films annealed in vacuum, $\mathrm{N}_{2}$ and $\mathrm{O}_{2}$," Physica B: Condensed Matter, vol. 388, no. 1-2, pp. 145$152,2007$.

[27] N. L. Tarwal, V. V. Shinde, A. S. Kamble et al., "Photoluminescence and photoelectrochemical properties of nanocrystalline $\mathrm{ZnO}$ thin films synthesized by spray pyrolysis technique," Applied Surface Science, vol. 257, no. 24, pp. 10789-10794, 2011.

[28] J. Y. Kim, S. H. Kim, H.-H. Lee et al., "New architecture for high-efficiency polymer photovoltaic cells using solution-based titanium oxide as an optical spacer," Advanced Materials, vol. 18, no. 5, pp. 572-576, 2006. 

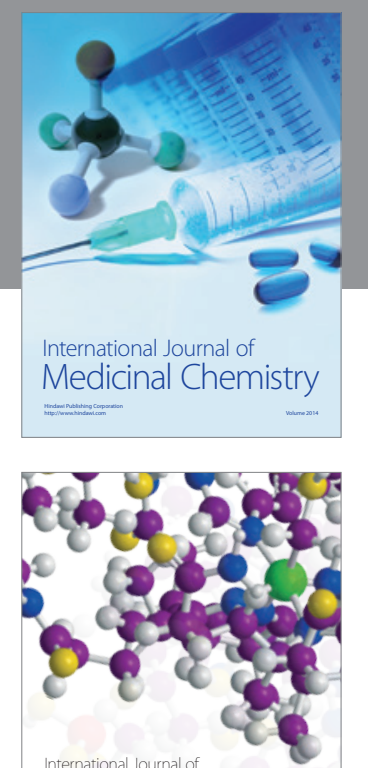

\section{Carbohydrate} Chemistry

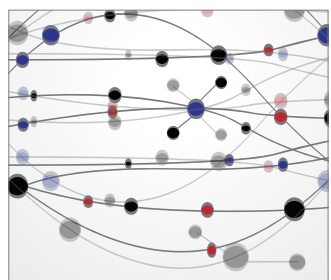

The Scientific World Journal
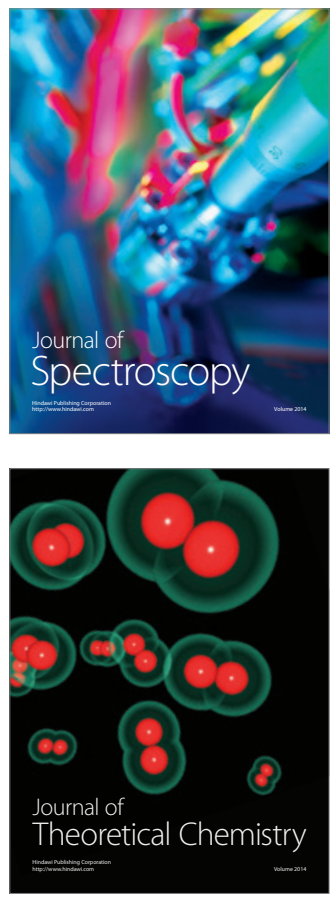
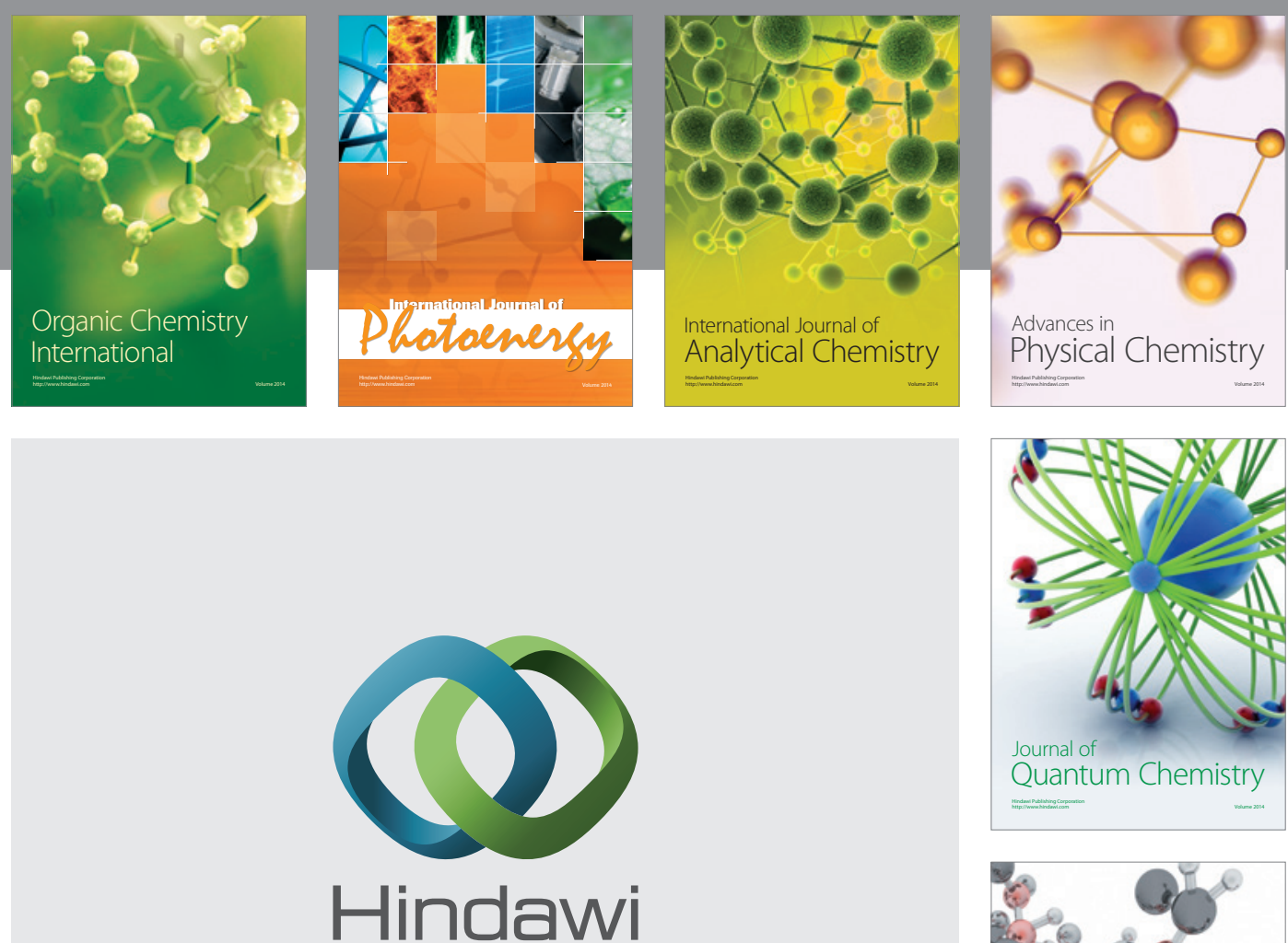

Submit your manuscripts at

http://www.hindawi.com

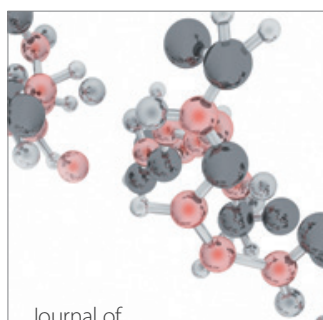

Analytical Methods

in Chemistry

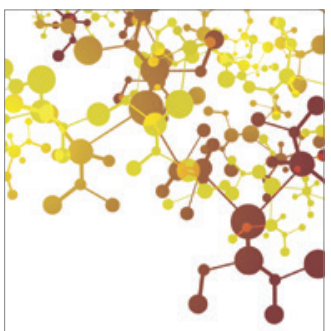

Journal of

Applied Chemistry

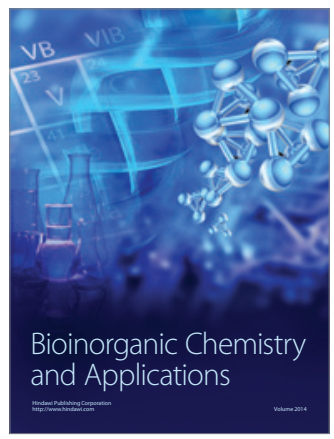

Inorganic Chemistry
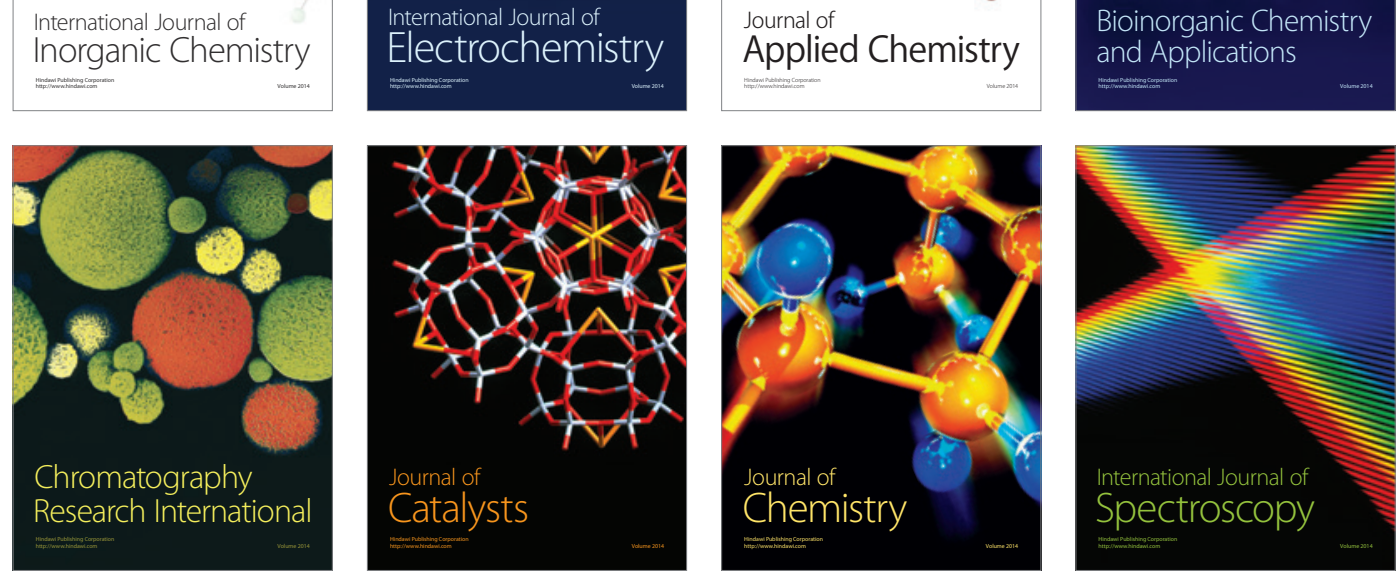